\title{
Perioperative Endocarditis Management in a Patient with Homozygous Sickle Cell Disease
}

\author{
Malgorzata Gozdzik ${ }^{1}$ Sergio Mariotti ${ }^{1}$ Michele Genoni ${ }^{2} \quad$ Alicja Zientara $^{3}$
}

1 Department of Anesthesiology, Stadtspital Triemli, Zurich,
Switzerland
2 Department of Cardiac Surgery, University Hospital Zurich, Zurich,
Switzerland
${ }^{3}$ Department of Cardiac Surgery, Triemli Hospital, Zurich, Switzerland

Thorac Cardiovasc Surg Rep 2019;8:e1-e4.

\begin{abstract}
Address for correspondence Dr. med. Alicja Zientara, Department of Cardiac Surgery, Triemli Hospital, Birmensdorferstrasse 497, Zurich 8063, Switzerland (e-mail: alicja_zientara@web.de).
\end{abstract}

\author{
Abstract \\ Keywords \\ - sickle cell disease \\ - cardiopulmonary \\ bypass \\ - endocarditis \\ - sickle crisis \\ - hemofiltration
}

Background Homozygous sickle cell disease (SCD) compounded with bacterial endocarditis makes open-heart surgery a multidisciplinary challenge.

Case description A 45-year-old African male patient with homozygous SCD presented with right heart decompensation, tricuspid regurgitation, and endocarditis of the aortic valve. Blood coulters were positive for coagulase-negative staphylococci. An emergent double valve replacement was successfully performed involving a multidisciplinary team.

Conclusion Homozygous SCD is associated with an increased risk of preoperative vaso-occlusive complications. Surgery with cardiopulmonary bypass can be performed, if hypothermia, hypoxia, acidosis, or low-flows are being avoided. Due to the lack of data, the adequate approach is still intuitive and requires standardization.

\section{Introduction}

Homozygous sickle cell disease (SCD) is an autosomal recessive inherited hemoglobinopathy generating hemoglobin SS (HbS). The prevalence is $5 \%$ of the world population with the highest frequency in India, Middle East, South Europe, and among Afro-Caribbean population. ${ }^{1}$ Hypothermia, hypoxia, acidosis, or low-flow states are conditions causing deformation to the characteristic sickle shape, increasing the risk of hemolysis, vaso-occlusion and subsequent end-organ damage. ${ }^{2}$ Cardiopulmonary bypass ( $\mathrm{CPB}$ ) use in multimorbide patients carries an increased risk of a sickling crisis requiring special perioperative management.

\section{Case Description}

A 45-year-old black African man treated with hydroxycarbamid due to SCD (HbS 96\%: electrophoresis 1 year prior to admission) was hospitalized because of a catheter-related, coagulasenegative staphylococcal (Staphylococcus epidermidis) sepsis and infection-induced sickle crisis. His medical history was significant for multiple sickle crises including GAVE (gastric antral vascular ectasia)-syndrome, portal hypertension, transfusion acquired $\mathrm{HCV}$ (hepatitis $\mathrm{C}$ virus) infection, and chronic ulcer of the lateral malleolus. After catheter explantation, an antimicrobial therapy with daptomycin was initiated after reviewing the resistance profile (oxacillin, ciproxin, gentamycin) and weighing the pros and cons of the medication related to the patient's health status and renal function. Because of the growth of multiresistant pseudomonas aeruginosa in tracheal secretions, therapy with meropenem was added 4 days later. Due to the sickle crisis and $\mathrm{Hb}$ of $7.0 \mathrm{~g} / \mathrm{dL}$, initial treatment included hydration with a transfusion of six red blood cell units (RBCs). During the first days of treatment, the patient developed acute kidney injury and cardiac decompensation. Echocardiography demonstrated a bicuspid aortic valve with a vegetation attached to the raphe between left- and noncoronary cusp accompanied by severe regurgitation. Further findings included significant right ventricle (RV) dilatation with severe tricuspid regurgitation, pulmonary hypertension received

August 21, 2018 accepted after revision November 16, 2018
DOI https://doi.org/

10.1055/s-0038-1676962. ISSN 2194-7635. (c) 2019 Georg Thieme Verlag KG
Stuttgart · New York

License terms

(1) $\Theta \circledast$ 
(RV/RA (right atrium)-gradient $41 \mathrm{~mm} \mathrm{Hg}$ ) and a left ventricular ejection fraction of $54 \%$. After the diagnosis of active endocarditis, the antimicrobial therapy was changed from daptomycin to vancomycin, still accompanied with meropenem for the resistant pseudomonas. The preoperative therapy included positive inotropic support and continuous hemodiafiltration due to acute renal failure and metabolic acidosis. Additional transfusion of two RBCs before surgery reduced $\mathrm{HbS}$ to $5.4 \%$.

Anesthesia was induced with propofol, ketamine, fentanyl, and rocuronium and was maintained with sevoflurane and remifentanil. During CPB, sevoflurane was replaced with propofol. Ventilation was controlled with a mixture of air and oxygen $\left(\mathrm{FiO}_{2}=0.6\right)$ and the end tidal carbon dioxide concentration was maintained between 4.0 and $5.0 \mathrm{kPa}$. The double-valve procedure was performed through median sternotomy with a routine aortic and bicaval cannulation. A heparin-coated open bypass circuit (Carmeda Medical Tubing, Medtronic, Brooklyn Park, Minnesota, United States), a hard-shell venous reservoir, a hollow fiber membrane oxygenator (Affinity Fusion with Carmeda Bioactive Surface, Medtronic, Brooklyn Park) with integrated polyester arterial line filter (40 mm pore size), and an arterial roller pump (Stockert S5, Sorin Group, Germany) were installed. Standard CPB priming was used, consisting of Ringer's lactate, heparine, tranexamic, acid and mannitol. Because of antithrombin III deficiency, 1,000 $\mathrm{U}$ of antithrombin and three RBCs were added. The flow rate was kept high at approximately $120 \%$ $(100 \%=4.49 \mathrm{Lpm})$ to maintain venous oxygen saturations between 80 and $85 \%$. Anticoagulation was performed according to standard protocol (heparine $300 \mathrm{U} / \mathrm{kg}$, ACT [anti-clotting time] $>350$ seconds). Perfusion pressure was kept above $70 \mathrm{~mm} \mathrm{Hg}$. Crystalloid cardioplegia was applied and aspirated immediately through sinus coronarius. Normothermia was maintained throughout the operation. During continous ultrafiltration to counteract hemodilution, the uncoated hemofilter (BC140 plus, Maquet Cardiopulmonary GmbH, Rastatt, Germany) had to be exchanged twice because of coagulation. After resection of the vegetation, the aortic valve was replaced ( $25 \mathrm{~mm}$ porcine prosthesis, Mosaic Ultra, Medtronic). The ventriculoarterial portion

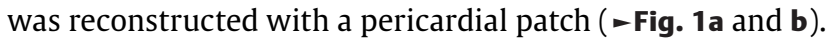
Dilated tricuspid annulus was reconstructed with a $32 \mathrm{~mm}$ Tri-Ad Adams tricuspid annuloplasty ring (Medtronic). After 92 minutes of aortic clamping and 20 minutes of reperfusion the patient was weaned from CPB easily. Exsanguinated blood in the oxygenator was discarded and not transfused. Additional eight RBCs were administrated peripherally through level 1 infuser without pressure. Intraoperative coagulation was optimized in accordance to thromboelastography with $2 \times 250 \mathrm{~mL}$ single donor thrombocytes and four fresh frozen plasma. Negative-balance hemofiltration was continued after surgery to remove excessive fluid loading and to reverse high potassium. No autologous cell-saver was used. (-Table 1: perioperative SCD-checklist)

On ICU, the patient was pharmacologically supported, kept warm with a warming blanket and extubated 8 hours postoperatively. Supplemental oxygen was given to keep oxygen saturation $>95 \%$. Gentamycin was added at the day of operation but the blood samples were repeatedly tested to be resistant and finally gentamycin was terminated after 3 days. Rifampicin was initiated at the postoperative day 3. Same day, meropenem was stopped and vancomycin was changed to Daptomycin after receiving negative samples of the explanted tissue and native valve with respect to the clinical status and renal function of the patient.

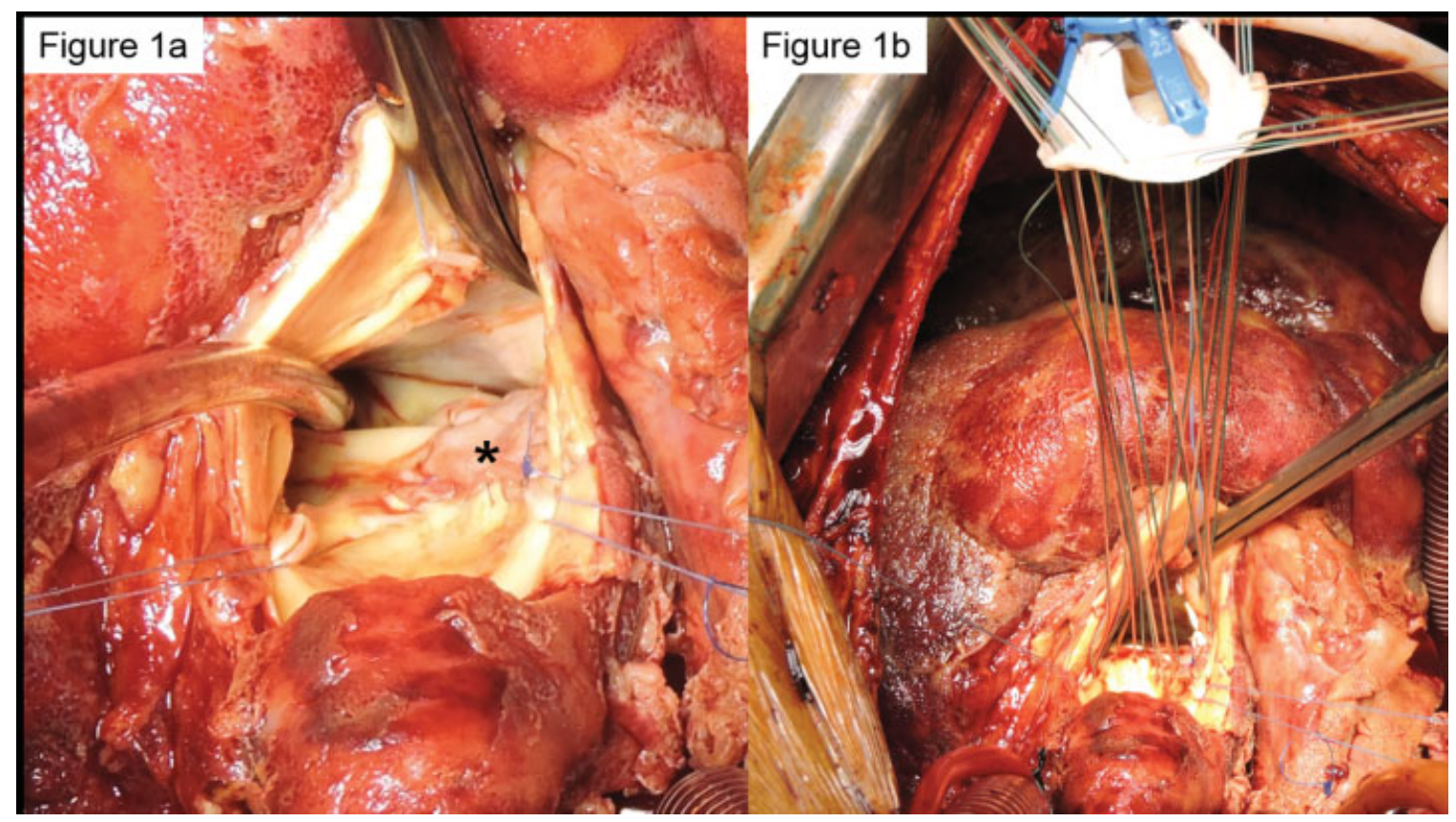

Fig. 1 (a) Aortic annulus after patch reconstruction of the ventriculoarterial portion $\left(^{*}\right)$; (b) the epicardium shows structural rough bearings of the surface. 
Table 1 Checklist for perioperative management of SCD under CPB

\begin{tabular}{|c|c|c|c|c|c|}
\hline & Hb level & $\begin{array}{l}\text { Body temperature } \\
\text { and venous stasis }\end{array}$ & Volemic status & $\begin{array}{l}\text { Oxygenation/ } \\
\text { acidosis }\end{array}$ & Cardioplegia \\
\hline $\begin{array}{l}\text { Preoperative } \\
\text { treatment }\end{array}$ & $\begin{array}{l}\text { Simple blood trans- } \\
\text { fusion, Hbs }<5 \% \\
\text { for cardiac surgery } \\
\text { (<30\% for major } \\
\text { surgery) }\end{array}$ & $\begin{array}{l}\text { Active warming } \\
\text { during induction } \\
\text { with FAWs }\end{array}$ & $\begin{array}{l}\text { Normovolemia with } \\
\text { perioperative fluid } \\
\text { balance }\end{array}$ & $\begin{array}{l}\text { Balanced metabolic } \\
\text { status, use of } \\
\text { hemofiltration } \\
\text { when needed }\end{array}$ & - \\
\hline $\begin{array}{l}\text { Intraoperative } \\
\text { management }\end{array}$ & $\begin{array}{l}\text { Blood for circuit } \\
\text { priming, avoidance } \\
\text { of pressure use } \\
\text { during peripheral } \\
\text { administration of } \\
\text { RBCs, avoidance of } \\
\text { cell-saver and } \\
\text { retransfusion of } \\
\text { exsanguinated } \\
\text { blood from the } \\
\text { oxygenator }\end{array}$ & $\begin{array}{l}\text { When proceeding } \\
\text { in normothermia: } \\
\text { active warming } \\
\text { with FAWs, under- } \\
\text { body conductive } \\
\text { heat mat, circulat- } \\
\text { ing water mattress, } \\
\text { or radiant warmer; } \\
\text { Avoidance of tour- } \\
\text { niquets and } \\
\text { compression }\end{array}$ & $\begin{array}{l}\text { Normovolemia with } \\
\text { a use of simple } \\
\text { transfusion, ultrafil- } \\
\text { tration and hemo- } \\
\text { filtration when } \\
\text { needed }\end{array}$ & $\begin{array}{l}\text { Hemofiltration dur- } \\
\text { ing CPB, buffers } \\
\text { when needed, } \\
\text { Higher flow rate } \\
\text { (120\%) to maintain } \\
\text { venous oxygen } \\
\text { saturations } \\
\text { between } 80 \text { and } \\
85 \%, \text { perfusion } \\
\text { pressure was kept } \\
\text { above } 70 \mathrm{~mm} \mathrm{Hg}\end{array}$ & $\begin{array}{l}\text { Crystalloid cardio- } \\
\text { plegia, aspiration } \\
\text { through sinus } \\
\text { coronarius, } \\
\text { continuous } \\
\text { hemofiltration } \\
\text { during CPB }\end{array}$ \\
\hline $\begin{array}{l}\text { Postoperative } \\
\text { treatment }\end{array}$ & $\begin{array}{l}\text { According to clini- } \\
\text { cal manifestations } \\
\text { (i.e., additional } \\
\text { transfusions) }\end{array}$ & $\begin{array}{l}\text { Active warming } \\
\text { with FAWs, posi- } \\
\text { tioning on ICU }\end{array}$ & $\begin{array}{l}\text { Negative-balance } \\
\text { hemofiltration to } \\
\text { remove excessive } \\
\text { fluid loading }\end{array}$ & $\begin{array}{l}\text { Balanced metabolic } \\
\text { status, use of } \\
\text { hemofiltration } \\
\text { when needed, pulse } \\
\text { oximetry monitor- } \\
\text { ing: keep } \\
\text { saturation > 95\% }\end{array}$ & - \\
\hline
\end{tabular}

Abbreviations: CPB, cardiopulmonary bypass; FAWs, frequent measured and forced air warmers; $\mathrm{Hb}$, hemoglobin; ICU, intensive care unit; RBCs, red blood, cells; SCD, sickle cell disease.

The hemodiafiltration was stopped 10 days after the surgery. The patient was discharged after 13 days postoperatively. Three months of follow-up demonstrated correct valve function and significant improvement of the clinical condition.

\section{Discussion}

Although SCD is an unusual hemoglobinopathy in the European population, it gains a growing importance due to the global migration process. Perioperative management should minimize potential sickling agents that may lead to deformation resulting in anemia, small-vessel occlusion, and organ damage. ${ }^{2-4}$

General hematologists' advice includes a reduction of the $\mathrm{HbS}$ level to an average of $5 \%$ before or at the time of cardiac surgery. ${ }^{4}$ The available methods include homologous transfusion, autotransfusion and partial exchange. Exchange transfusions do not alter the hematocrit or viscosity but replace sickle cells with normal erythrocytes and suppress further HbS production. Simple transfusion expands the normal red cell mass thereby improving oxygen delivery at the cost of increasing blood viscosity. Autologous transfusion with the use of cell-saver systems on the one hand, reduce the need for homologous blood transfusion but also make the filtered blood more prone to sickling. ${ }^{5}$ Despite well-known transfusion-related complications, simple blood transfusion seems to be beneficial also in case of Hb levels $>7 \mathrm{~g} / \mathrm{dL}^{6}$ Although many clinical reports indicate preoperative exchange transfusion as the method of choice, there are also cases of successful intraoperative transfusions using blood for circuit priming. ${ }^{5,6}$ As discussed in the recent overview of Crawford et al the standard recommendation on preoperative exchange transfusions is changing by gaining a wider focus on the negative aspects, that is, association of large volume transfusions and coagulopathy, culminating free iron, and free radical organ damage. All in all, there is no randomized study that supports strongly one of both methods. There might be a tendency to a more conservative transfusion approach targeting a preoperative level $>10 \mathrm{~g} / \mathrm{dL}$ than a $\mathrm{HbS}$ fraction $<30 \%$ reporting similar surgical outcomes. $^{7}$ In our anemic patient, pre- and intraoperative transfusions were chosen as the most adequate option, as the HbS was almost $5 \%$ preoperatively after having received cumulatively eight RBCs over a time period of 12 days because of decreasing $\mathrm{Hb}$ levels due to infectious status.

In view of vasoconstriction, normothermia was described as the most frequent option. ${ }^{5}$

There is, however, evidence that hypothermia appears in vitro to slow polymerization of HbS and delay the sickling of the RBCs. ${ }^{5}$ Few papers report intraoperative hypothermia as a successful method in SCD patients undergoing $\mathrm{CPB} .{ }^{8}$ In our patient with acute renal injury and chronic malleolus ulcer, we chose normothermia to avoid vasoconstriction and sequential complications.

Focusing on cardioplegia, described methods include warm blood or crystalloid infusions and specially designated combinations. ${ }^{3}$ Theoretically, crystalloid, cold cardioplegia should be avoided because of the possibility of sickling and vascular occlusion in the coronary microvasculature. Nevertheless, no negative effects concerning myocardial infarction 
or additional inotropic support during intensive care unit (ICU) stay have been reported. ${ }^{9}$ Removal of potassium and cardioplegia can be provided by continuous hemofiltration and aspiration through the sinus coronarius by the surgeon.

Hypoxia can be successfully avoided using venous oxygen saturation as a reliable oxygenation marker, with SvO2 levels of $80 \% .^{3,5}$ After extubation pulse oximetry monitoring should be continued to keep saturation $>95 \%$. Low-flow states, hypovolemia and acidosis can be monitored and avoided with the use of $\mathrm{CPB}$ and continuous hemofiltration.

In summary, $\mathrm{CPB}$ can be well tolerated after individual adaptation of the standard protocol and avoidance of risk factors. The preoperative exchange transfusion does not appear to be necessary and a simple euvolemic transfusion at the time of operation can be beneficial in anemic patients. Crystalloid cardioplegia seems to be a safe method. Multidisciplinary planning, taking into account all risk factors, is required for a safe and individually adjusted therapy.

\section{Conflict of Interest}

None declared.

\section{References}

1 Firth PG. Anaesthesia for peculiar cells-a century of sickle cell disease. Br J Anaesth 2005;95(03):287-299

2 Steinberg MH. Management of sickle cell disease. N Engl J Med 1999;340(13):1021-1030

3 Hemming AE. Pro: exchange transfusion is required for sickle cell trait patients undergoing cardiopulmonary bypass. J Cardiothorac Vasc Anesth 2004;18(05):663-665

4 Yousafzai SM, Ugurlucan M, Al Radhwan OA, Al Otaibi AL, Canver CC. Open heart surgery in patients with sickle cell hemoglobinopathy. Circulation 2010;121(01):14-19

5 Sachithanandan A, Nanjaiah P, Wright CJ, Rooney SJ. Mitral and tricuspid valve surgery in homozygous sickle cell disease: perioperative considerations for a successful outcome. J Card Surg 2008;23(02):167-168

6 Wanko SO, Telen MJ. Transfusion management in sickle cell disease. Hematol Oncol Clin North Am 2005;19(05):803-826, v-vi

7 Crawford TC, Carter MV, Patel RK, et al. Management of sickle cell disease in patients undergoing cardiac surgery. J Card Surg 2017; 32(02):80-84

8 Fox MA, Abbott TR. Hypothermic cardiopulmonary bypass in a patient with sickle-cell trait. Anaesthesia 1984;39(11):1121-1123

9 Head CA, Brugnara C, Martinez-Ruiz R, et al. Low concentrations of nitric oxide increase oxygen affinity of sickle erythrocytes in vitro and in vivo. J Clin Invest 1997;100(05):1193-1198 